\title{
Inventory and incidence of plant diseases affecting vegetables in selected areas in the Visayas and Mindanao
}

\author{
Lucia M. Borines ${ }^{1 *}$, Joy Adeline C. Nuñez, Nickie Duero, Rezel M. Sagarino', \\ Fely R. Cañete', Elvira L. Oclarit', Reny G. Gerona', Sandra McDougall ${ }^{2}$ and Len \\ Tesoriero $^{2}$
}

\begin{abstract}
The identification of different vegetable diseases in a particular area is key to managing them. An inventory of diseases affecting important vegetables was conducted in selected areas in the Visayas, and Mindanao. The vegetable diseases were documented in Leyte, Samar, Biliran, Bohol and Claveria Misamis Oriental. Disease surveys were conducted and samples were brought to the laboratory for diagnosis. Pathogenicity tests were conducted for uncommon diseases and PCR and nest PCR assays were done for suspected Phytoplasma diseases. The most common and major disease that affect vegetables in Eastern Visayas is bacterial wilt caused by Ralstonia solanacearum which attacked tomato, pepper, eggplant, bittergourd and was also detected in a wilt infected lettuce. Downy mildew is another which affected bittergourd and pechay. Cercospora diseases were found to commonly affect pepper, eggplant, tomato and bittergourd. Phytophthora diseases were common in tomato, eggplant, pepper and pechay. Fusarium wilt had affected tomato and pepper in Claveria Misamis Oriental, but not common in Eastern Visayas. Emerging diseases were recorded such as Phytoplasma and Corynespora cassiicola which affected tomato and bittergourd, bacterial canker, bacterial speck, target spot, Septoria leaf spot and pith necroses were also found affecting tomato. Information gained from the inventory informed the production of extension materials aimed at farmers and farm extension officers.
\end{abstract}

Keywords: Phytoplasma, tomato, ampalaya, eggplant, lettuce, pechay, sweet pepper, emerging diseases

\section{INTRODUCTION}

Plant diseases are a major contributor to agricultural production losses. Vegetable production, especially in Eastern Visayas, is greatly hampered by the the occurrence of plant diseases causing yield and economic losses. The accurate

\footnotetext{
' Visayas State University, Visca, Baybay City, Leyte, Philippines

${ }^{2}$ Department of Primary Industries (DPI), Australia, NSW, Australia

* Corresponding Author. Address: Department of Pest Management, Visayas State University, Visca, Baybay City, Leyte, 6521-A Philippines; Email: lucyborines@vsu.edu.ph DOI: $10.32945 /$ atr39sb2.2017
} 
Inventory and incidence of plant diseases affecting vegetables

diagnosis and identification of specific diseases attacking vegetable crops are necessary for the formulation of right and accurate management strategies. Most farmers do not know what specific diseases are occurring on their farms, do not know the correct control measures to apply, and rely mostly on pesticides. A basic knowledge of what diseases are present in an area is a pre-requisite for identifying an effective disease management strategy.

De la Cueva et al, published the book "Pests and Diseases of Economically Important Crops in the Philippines" in 2015. Similarly Tangonan \& Quebral (1992) and Tangonan (1999) published the "Host index of plant diseases in the Philippines" (1992 \& 1999 edition), but not all diseases of tomato, eggplant, pepper, bittergourd, pechay and lettuce were included in these publications.

New diseases emerge from time to time and they need to be monitored and identified to prevent them from causing epidemics. In this inventory, the major and emerging diseases of vegetables are identified. Identification of the causal organisms of diseases effecting vegetables and information on disease control measures is useful for vegetable researchers, agricultural technicians, disease management specialists and the vegetable farmers themselves.

\section{MATERIALS AND METHODS}

\section{Areas and Period When Vegetable Diseases Where Sampled}

Most of the diseases that are included in this paper were documented from the island of Leyte in Eastern Visayas, with some from the vegetable areas of Samar and Biliran islands and a few samples were also collected from collaborating sites of the ACIAR-ICM project, ie, Bilar, Pilar and Jagna in Bohol, Claveria, Misamis Oriental and Pamuhatan, Marilog, Davao City. The disease inventory was carried out between July 2013 - June 2017. A few diseases, identified in an earlier project (2010-2012) have been included in this paper.

\section{Disease Collection and Pathogen Identification}

Disease specimens were collected and brought back to the laboratory for clinical examination of the signs of pathogens. Symptoms were characterised, described and recorded. The associated pathogens were also documented and described. For common diseases, the associated microorganisms were identified using taxonomic keys, available printed references and the internet. Pathogen isolations and pathogenicity tests were conducted for uncommon diseases. Tomato, eggplant, bittergourd, pepper and pechay seedlings were maintained in the screenhouse for pathogenicity testing.

Molecular detection of Phytoplasma diseases were also conducted using the polymerase chain reaction (PCR) and nest PCR. DNAs were extracted from samples of suspected phytoplasma diseases and subjected to initial PCR using universal phytoplasma primer P1/P7 (Deng \& Hiruki 1991) then nest PCR using $R_{16} F_{2} n / R_{16} R_{2}$ primers (Lee et al 1995). Immuno-diagnostic strips from AGDIA and Pocket Diagnostics were used to detect viruses such as cucumber mosaic virus (CMV), and tomato spotted wilt virus (TSWV) and tobacco mosaic virus (TMV) and bacteria particularly, Clavibacter michiganensis subsp. michiganensis and Ralstonia solanacearum. 


\section{RESULTS AND DISCUSSION}

The different diseases that had been monitored from tomato, the places where they were collected, and causal organism identified are shown in Table 1. Six tomato diseases were caused by prokaryotic microorganisms, namely bacterial wilt, bacterial spot, bacterial canker, bacterial speck, pith necrosis and tomato stunt/little leaf disease which was caused by Phytoplasma. Bacterial wilt was very common and is a major problem in Eastern Visayas. Bacterial spot was also common, particularly during rainy months. Tomato showing bacterial leaf spots were once thought only to be caused by Xanthomomonas axonopodis pv. vesicatoria, but recent pathogenicity tests and diagnostic study show that smaller spots that do not reach more than $2 \mathrm{~mm}$ diameter is actually bacterial speck which is caused by Pseudomonas syringae pv. tomato. Bacterial canker, an emerging disease was monitored only in Cabintan, in the highlands of Ormoc City and San Isidro, Leyte. Bacterial pith necrosis which is also an emerging disease was monitored in Pananawan Maasin City and Sogod, Southern Leyte. It was once thought to be caused by Ralstonia solanacearum until this paper. Pith necrosis causes a hollow stem in tomato which is not seen in bacterial wilt. Tomato stunt little leaf was only collected from one farm in Gabas, Baybay City and was confirmed to be due to Phytoplasma through PCR and nest PCR analysis.

Table 1. Diseases of tomatoes, symptom description and causal organism

\begin{tabular}{|c|c|c|}
\hline \multicolumn{3}{|c|}{ Disease due to Prokaryotes (True Bacteria \& Mollicutes) } \\
\hline Disease & Description/Symptoms & Causal Organism \\
\hline $\begin{array}{l}\text { Bacterial Wilt } \\
\text { (major disease \& } \\
\text { commonly found in } \\
\text { Eastern Visayas) }\end{array}$ & $\begin{array}{l}\text { Plants wilt, internal stem turns brown, adventitious } \\
\text { roots form on stems, spread in contaminated water } \\
\text { and soil. }\end{array}$ & $\begin{array}{l}\text { Ralstonia solanacearum/ } \\
\text { Ralstonia } \\
\text { pseudosolanacearum }\end{array}$ \\
\hline $\begin{array}{l}\text { Bacterial Spot } \\
\text { (major, common } \\
\text { during wet season) }\end{array}$ & $\begin{array}{l}\text { Symptoms begin as small, angular or round lesions } \\
\text { on young leaves and become dark and water-soaked } \\
\text { and sometimes with a yellow halo. Infected green } \\
\text { fruit also have small water-soaked spots. Severe } \\
\text { infections cause premature yellowing and early } \\
\text { senescence of plants. Spread with infected seed and } \\
\text { contaminated water and soil. }\end{array}$ & $\begin{array}{l}\text { Xanthomonas axonopodis } \\
\text { pv. vesicatoria (syn. } \\
\text { Xanthomonas campestris } \\
\text { pv. vesicatoria) }\end{array}$ \\
\hline $\begin{array}{l}\text { Bacterial Canker } \\
\text { (emerging, occasional } \\
\text { Figure } 1 \mathrm{a}-1 \mathrm{~b} \text { ) }\end{array}$ & $\begin{array}{l}\text { Scorched or "firing" spots/markings on leaflets and } \\
\text { wilting of lower leaves; infection may advance to } \\
\text { vascular system resulting to plant collapse; brown } \\
\text { raised cankers on fruit which may have pale halos } \\
\text { called "bird's eye spots". }\end{array}$ & $\begin{array}{l}\text { Clavibacter michigenensis } \\
\text { sub sp. michiganensis }\end{array}$ \\
\hline $\begin{array}{l}\text { Pith Necrosis } \\
\text { (occasional Figure } \\
\text { 1c) }\end{array}$ & $\begin{array}{l}\text { Small pinpoint water-soaked spots appear on the } \\
\text { stems that enlarge; stem becomes hollow with a rot } \\
\text { in the center and sometimes crack. Spread in water } \\
\text { and by handling plant. Bacteria enter through } \\
\text { wounds. Disease is favoured by too much nitrogen } \\
\text { fertiliser. }\end{array}$ & Pseudomonas sp. \\
\hline
\end{tabular}


Inventory and incidence of plant diseases affecting vegetables

Table 1 continued

\begin{tabular}{llll}
\hline \multicolumn{3}{c}{ Diseases due to Prokaryotes (True Bacteria \& Mollicutes) } & \multicolumn{1}{c}{ Causal Organism } \\
\hline \multicolumn{1}{c}{ Disease } & \multicolumn{1}{c}{ Description/Symptoms } & \\
$\begin{array}{l}\text { Tomato Stunt/Little } \\
\text { Leaf } \\
\text { (emerging but rare } \\
\text { Figure1d) }\end{array}$ & $\begin{array}{l}\text { Leaves are small, curled upwards and yellowish- } \\
\text { green or purple. Interveinal chlorosis seen on young } \\
\text { leaves. Leaves along midrib do not expand properly. } \\
\text { General stunting of the plant. Blooms fail to set in } \\
\text { more severely affected plant }\end{array}$ & \\
\hline $\begin{array}{l}\text { Bacterial Speck } \\
\text { (occasional Figure } \\
\text { 1e-f) }\end{array}$ & $\begin{array}{l}\text { Necrotic spots/specks with not more than 2mm in } \\
\text { diameter and initiation of marginal necrosis wherein }\end{array}$ & $\begin{array}{l}\text { Pseudomonas syringae } \\
\text { pv.tomato }\end{array}$ \\
\hline \multicolumn{3}{c}{ yellowing of the leaf margin can be observed. } & \\
\hline
\end{tabular}

Seedling Damping-off

(major but

occasional. common

in unsterilized potting

mix)

Fusarium wilt
Fusarium Crown and
Root Rot
(major fusarium wilt
common in Claveria.
Fusarium crown rot
monitored in Leyte)

Patches of young plants wilt and die. Lower stems become thin and watery. Root systems turn brown and rot. Spread in contaminated water and soil, and with some flies.

Pythium, Phytophthora, Fusarium, Rhizoctonia spp.

Older leaves turn yellow then dry out. Plants wilt and die. When cut open vascular tissue inside stems is brown. This may extend up to the flower stalks. For crown and root rot, there is brown discoloration of the base of basal part and rotting of the stem. Spread by spores that survive for years in contaminated soil.

Fusarium oxysporum $\mathrm{f}$. sp. lycopersici/ Fusarium oxysporum $f$. $s p$. radices lycopersici

Stunted plants will wilt and die. Dense white threads

Sclerotium Wilt

/Southern Blight (minor but prevalent) of fungal growth develops around the rotting stem base. Smooth white-brown spherical structures ( 1Sclerotium rolfsii $3 \mathrm{~mm}$ in diameter) develop in this fungal growth.
Late Blight/Fruit rot (major, occasional common in humid climate)

\begin{tabular}{l} 
Leaf Mold \\
(major, common) \\
\hline \\
Powdery Mildew \\
(major, occasional)
\end{tabular}

Dark brown lesions develop on stems and fruit causing plant to wilt and die. White mycelia may cover dark lesions during humid weather. Spread by air-borne and water-borne spores.

Light yellowish/brownish blotches appear on the upper leaf surface with furry brown fungal growth on the underside.

Affected older leaves wither which may cause the entire plant to die. Spread by air-borne spores
Phytophthora infestanscause both late blight and fruit rot-Phytophthora capsici-commonly cause fruit rot fuligena
Pseudocercospora

Pale spots first appear on the upper leaf surface. White powdery fungal growth develops on both sides of leaves. Leaves gradually turn yellow, die, and fall

Oidium neolycopersici borne spores. 
Borines et al

Table 1 continued

\begin{tabular}{|c|c|c|}
\hline \multicolumn{3}{|c|}{ Disease due to Fungi and Fungal-Like Organisms } \\
\hline Disease & Description/Symptoms & Causal Organism \\
\hline $\begin{array}{l}\text { Target Spot } \\
\text { and early blight } \\
\text { (target spot is } \\
\text { emerging Early bight } \\
\text { is common in the } \\
\text { highlands Figure } 1 \mathrm{~g} \text { ) }\end{array}$ & $\begin{array}{l}\text { Symptoms of these two diseases are similar and } \\
\text { may be misdiagnosed. Lesions start as small } \\
\text { pinpoint water-soaked frequently ringed spots on } \\
\text { the upper surface which later turn brown and } \\
\text { increasing in size. In early blight, however, lesions } \\
\text { with rings are usually surrounded by yellow halo and } \\
\text { may coalesce forming blighted leaves leading to } \\
\text { premature defoliation. In the earlier stages, may be } \\
\text { confused with bacterial spot. Brown Lesions may } \\
\text { form on stems. }\end{array}$ & $\begin{array}{l}\text { Target spot - caused by } \\
\text { Corynespora cassiicola } \\
\text { Early Blight - caused by } \\
\text { Alternaria tomatophila }\end{array}$ \\
\hline $\begin{array}{l}\text { Septoria Leaf Spot } \\
\text { (minor, common in } \\
\text { highlands Figure } 1 \mathrm{~h} \text { ) }\end{array}$ & $\begin{array}{l}\text { Small dark circular spots }(\sim 1-3 \mathrm{~mm}) \text { appear on } \\
\text { older leaves and stems. These enlarge to } 6 \mathrm{~mm} \text {, } \\
\text { turn greyish with dark fungal structures in their } \\
\text { center. Spread with seed, and by air and water- } \\
\text { borne spores. }\end{array}$ & Septoria lycopersici \\
\hline $\begin{array}{l}\text { Anthracnose } \\
\text { (minor, occasional) }\end{array}$ & $\begin{array}{l}\text { Small sunken water soaked circular spots on fruit } \\
\text { which later become darker than the surrounding } \\
\text { tissue. The spots later become depressed and } \\
\text { develop concentric markings. Mainly affects ripe } \\
\text { fruit. }\end{array}$ & Colletotrichum coccodes \\
\hline \multicolumn{3}{|c|}{ Diseases due to Virus } \\
\hline $\begin{array}{l}\text { Tomato yellow } \\
\text { leaf curl virus } \\
\text { (major, occasional } \\
\text { but common in } \\
\text { certain areas) }\end{array}$ & $\begin{array}{l}\text { Plants are stunted, young leaves yellow and curl. } \\
\text { Spread by whitefly (Bemisia tabaci). }\end{array}$ & $\begin{array}{l}\text { Tomato yellow leaf curl } \\
\text { virus (TYLCV) }\end{array}$ \\
\hline $\begin{array}{l}\text { Tomato mosaic } \\
\text { (major, occasional) }\end{array}$ & $\begin{array}{l}\text { Leaves have patches of yellow or white marks. } \\
\text { Growth can become twisted and young shoots } \\
\text { stunted. Some virus strains cause dark marks to } \\
\text { form inside the walls of fruit. Spread by handling } \\
\text { plants and in contaminated soil where susceptible } \\
\text { plants were previously grown. }\end{array}$ & $\begin{array}{l}\text { Tobacco mosaic } \\
\text { virus (TMV) }\end{array}$ \\
\hline $\begin{array}{l}\text { Tomato mosaic } \\
\text { (major, common) }\end{array}$ & $\begin{array}{l}\text { Plants are stunted with distorted and twisted } \\
\text { young growth. Leaves have pale green and dark } \\
\text { green areas. Leaves can have 'shoestring' } \\
\text { appearance. Spread with infected seed and by } \\
\text { aphids }\end{array}$ & $\begin{array}{l}\text { Cucumber mosaic virus } \\
\text { (CMV) }\end{array}$ \\
\hline $\begin{array}{l}\text { Tomato Spotted Wilt } \\
\text { (occasional) }\end{array}$ & $\begin{array}{l}\text { Plants are stunted and may wilt and die. Leaves } \\
\text { have black streaks and ring markings. Fruit have } \\
\text { yellow or dark blotches, often forming concentric } \\
\text { rings. Spread by thrips. }\end{array}$ & $\begin{array}{l}\text { Tomato spotted wilt virus } \\
\text { (TSWV) }\end{array}$ \\
\hline
\end{tabular}


Inventory and incidence of plant diseases affecting vegetables

Table 1 continued

\begin{tabular}{lll}
\hline \multicolumn{2}{c}{ Nematode Diseases } \\
\hline $\begin{array}{l}\text { Root Knot } \\
\text { (major, common) }\end{array}$ & $\begin{array}{l}\text { Plants are stunted and may wilt during the day. } \\
\text { Galls form on roots. }\end{array}$ & $\begin{array}{l}\text { Meloidogyne } \\
\text { incognita and other } \\
\text { Meloidogyne species }\end{array}$ \\
\hline Other Nematodes & Stunting of plants & $\begin{array}{l}\text { Rotylenchulus sp. } \\
\text { Hemicyciophora } \\
\text { Helicotylenchus } \\
\text { Xiphinema }\end{array}$ \\
\hline
\end{tabular}

Two fusarium diseases were monitored in tomato: fusarium wilt caused by Fusarium oxysporum s.sp.lycopersici which was common in Claveria, Misamis Oriental, and fusarium crown and root rot caused by Fusarium oxysporum $f$. sp. radices lycoprsici which was monitored at VSU, Baybay City in Leyte. Sclerotium wilt/Southern Blight was a common problem of tomato in Eastern Visayas. Two Phytophthora species were found infecting tomato: Phytophthora infestans causing late blight and fruit rot, and Phytophthora capsici which commonly caused fruit rot but not much blighting of shoots.

Five other diseases were caused by fungi namely: damping off which was caused by either Pythium, Phytophthora, Fusarium or Rhizoctonia spp., Sclerotium wilt or southern blight caused by Sclerotium rolfsii, leaf mold caused by Pseudocercospora fuligena, anthracnose caused by Colletotrichum coccodes, Septoria leaf spot caused by Septoria lycopersici and target spot caused by Corynespora cassiicola. Three virus diseases were identified: cucumber mosaic virus (CMV), tobacco and tomato mosaic virus caused by TMV and tomato spotted wilt virus (TSWV). Five nematodes were monitored at the Experimental site of the Visayas State University: Meloidogyne incognita, Rotylenchulus, Hemicycliophora $\mathrm{sp}$, Helicotylenchus and Xiphinema.

Among the diseases of tomato, five are considered emerging because there are no previous published reports of them in the Philippines. They are: bacterial canker (Figure 1a-b), pith necrosis (Figure 1c), tomato stunt Phytoplasma (Figure 1d), bacterial speck (Figure 1e-f), target spot (Figure 1g) and Septoria leaf spot (Figure $1 \mathrm{~h}$ ). In terms of disease incidence, bacterial wilt, bacterial spot and leaf mould were the most prevalent in Eastern Visayas affecting tomato in different areas. Late blight and fruit rot caused by Phytophthohra infestans and Phytophthora capsici, respectively also occurred at high incidence, in a few of the sampled areas. 
Borines et al

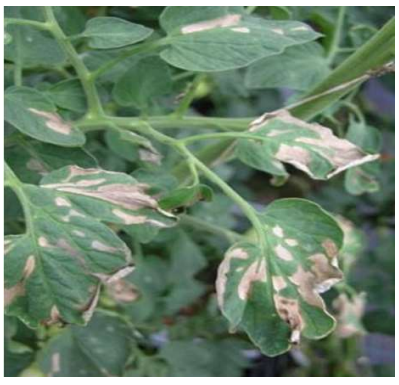

a

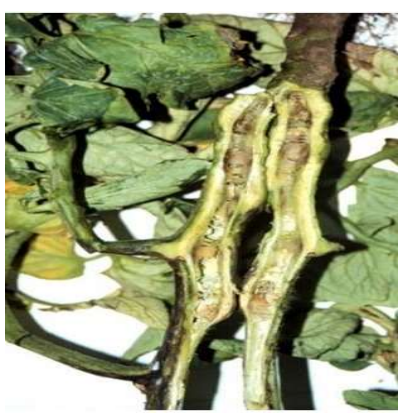

C

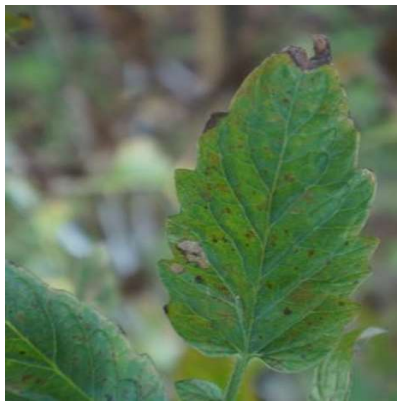

e

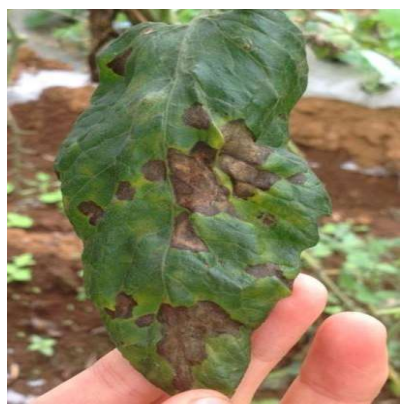

g

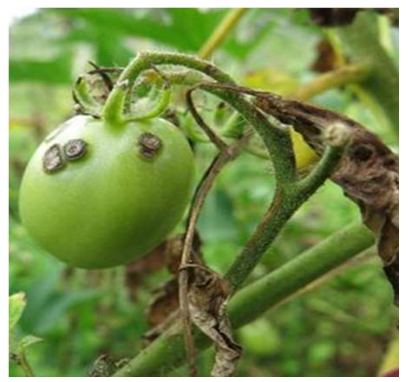

b

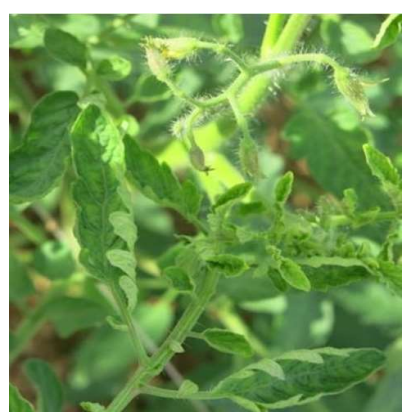

d
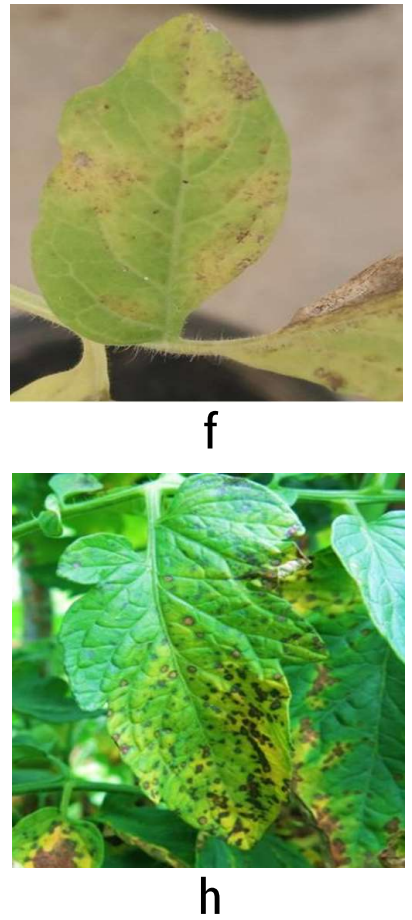

Figure 1. Identified emerging diseases of tomato: a-b) bacterial canker, $c$ ) pith necrosis, d) tomato stunt/little leaf, e-f) bacterial speck, g) target spot and h) Septoria leaf spot 
Inventory and incidence of plant diseases affecting vegetables

Two bacterial diseases (bacterial wilt \& bacterial spot), nine fungal diseases (damping off, fusarium wilt, sclerotium wilt, anthracnose, cercospora leaf spot, powdery mildew, basal stem rot, Choanephora blight \& sooty mold) and three viruses were monitored from pepper (Table 2). The most wide-spread disease of pepper is Cercospora leaf spot or "frogeye spot" occurring in almost all areas sampled. Bacterial wilt is also common and is a major problem in sweet pepper production, particularly in Eastern Visayas. Fusarium wilt was common in Claveria Misamis Oriental. Powdery mildew was recorded in just two areas, ie, in Cabintan, Ormoc and at the VSU experimental site. Anthracnose, caused by different Colletotrichum species, was commonly infecting sweet pepper fruit. Sooty mold was commonly found in pepper grown under protective cultivation. Although not directly infecting sweet pepper, it covers the leaf surfaces and can reduce photosynthesis. Choanephora blight, caused by Choanaephora cucurbitarum and powdery mildew caused by Leveillula taurica are previously unreported in Eastern Visayas (Figure 2).

Table 2. Diseases of peppers, symptom description and causal organism

\begin{tabular}{|c|c|c|}
\hline \multicolumn{3}{|c|}{ Diseases due to Bacteria and Mollicutes } \\
\hline & Description/Symptoms & Causal Organism \\
\hline $\begin{array}{l}\text { Bacterial Wilt } \\
\text { (major disease and } \\
\text { commonly found in } \\
\text { Eastern Visayas) }\end{array}$ & $\begin{array}{l}\text { Sudden wilting of the foliage and the whole plant, } \\
\text { internal vascular darkening of root and stem that } \\
\text { leads to stem damage and death of the affected } \\
\text { plant. }\end{array}$ & $\begin{array}{l}\text { Ralstonia solanacearum/ } \\
\text { Ralstonia } \\
\text { pseudosolanace } \\
\text { arum }\end{array}$ \\
\hline $\begin{array}{l}\text { Bacterial Spot } \\
\text { (major, common during } \\
\text { wet season) }\end{array}$ & $\begin{array}{l}\text { Small, angular or round lesions on leaves and fruit. } \\
\text { Spots become dark and water-soaked and } \\
\text { sometimes with a yellow halo. Severe infections } \\
\text { cause premature yellowing and early senescence of } \\
\text { plants. Bacteria are seed borne and spread with } \\
\text { water. }\end{array}$ & $\begin{array}{l}\text { Xanthomonas } \\
\text { euvesicatoria, }\end{array}$ \\
\hline \multicolumn{3}{|c|}{ Diseases due to Fungi and Fungal -like Organisms } \\
\hline $\begin{array}{l}\text { Seedling Damping-off } \\
\text { (major but occasional. } \\
\text { Common in unsterilized } \\
\text { potting mix) }\end{array}$ & $\begin{array}{l}\text { Seeds rot before emergence of stem of seedlings at } \\
\text { ground level brown, thin and plants fall over. Root } \\
\text { systems turn brown and rot. Spread in } \\
\text { contaminated water and soil, and with some flies. }\end{array}$ & $\begin{array}{l}\text { Pythium, Fusarium, } \\
\text { Sclerotium, } \\
\text { Phytophthora, or } \\
\text { Rhizoctonia spp. }\end{array}$ \\
\hline $\begin{array}{l}\text { Fusarium wilt } \\
\text { (major, common in } \\
\text { Claveria, Misamis } \\
\text { Oriental) }\end{array}$ & $\begin{array}{l}\text { Initial yellowing of the foliage which starts at the } \\
\text { lower leaves, loss of turgidity and witting of the } \\
\text { whole plant. Internal browning of the stem. }\end{array}$ & $\begin{array}{l}\text { Fusarium oxysporum f } \\
\text { sp. lycopersici }\end{array}$ \\
\hline $\begin{array}{l}\text { Sclerotium Wilt /Southern } \\
\text { Blight } \\
\text { (major, occasional) }\end{array}$ & $\begin{array}{l}\text { Rotting of the base and wilting of the plant. } \\
\text { Whitish mycelia and tiny round white to brown } \\
\text { sclerotial bodies are found at the base near the } \\
\text { soil line. }\end{array}$ & Sclerotium rolfsii \\
\hline $\begin{array}{l}\text { Cercospora Leaf } \\
\text { Spot/Frog-eye spot } \\
\text { (major, common) }\end{array}$ & $\begin{array}{l}\text { Leaf lesions with a dark margin. The centre can } \\
\text { drop out leaving a hole in the leaf. Can also affect } \\
\text { stems. Spread by air-borne spores and favoured by } \\
\text { wet conditions. }\end{array}$ & Cercospora capsici \\
\hline
\end{tabular}


Borines et al

Table 2 continued

\begin{tabular}{|c|c|c|}
\hline \multicolumn{3}{|c|}{ Disease due to Fungi and Fungal-Like Organisms } \\
\hline & Description/Symptoms & Causal Organism \\
\hline $\begin{array}{l}\text { Anthracnose } \\
\text { (major, common) }\end{array}$ & $\begin{array}{l}\text { Sunken soft lesions on fruit, with pink fungal } \\
\text { spores in the centre. Fruit rot as they ripen in wet } \\
\text { conditions. Spores spread by water splash. }\end{array}$ & $\begin{array}{l}\text { Colletotrichum spp. } \\
\text { (C. gloeosporioides, C. } \\
\text { capsici, C. acutatum, } \\
\text { and C. coccodes) }\end{array}$ \\
\hline $\begin{array}{l}\text { Powdery Mildew } \\
\text { (major, occasional: Figure } \\
2 a \& 2 b \text { ) }\end{array}$ & $\begin{array}{l}\text { Powdery white appearance on older leaves, } \\
\text { especially during warm humid nights. Severely } \\
\text { affected leaves yellow and fall. Spread by air- } \\
\text { borne spores and favoured by shaded } \\
\text { conditions. }\end{array}$ & Leveillula taurica \\
\hline $\begin{array}{l}\text { Basal Stem Rot } \\
\text { (major, occasional) }\end{array}$ & $\begin{array}{l}\text { Darkening and girdling of the basal part of the } \\
\text { stem and roots leading to wilting of the above } \\
\text { ground parts of the plant base, with or without } \\
\text { mycelial and sclerotial bodies }\end{array}$ & $\begin{array}{l}\text { Phytophthora, Sclerotium } \\
\text { rolfsii, Rhizoctonia solani }\end{array}$ \\
\hline $\begin{array}{l}\text { Choanephora Blight } \\
\text { (minor, rare: Figure 2c \& } \\
\text { 2d) }\end{array}$ & $\begin{array}{l}\text { Water-soaked leaf lesions appear on the leaves, } \\
\text { blighting margins and leaftips. Stiff, silvery mass } \\
\text { of hairy strands grow out of the affected leaf } \\
\text { tissue, topped with a black ball. Spread by air } \\
\text { borne spores. }\end{array}$ & $\begin{array}{l}\text { Choanephora } \\
\text { cucurbitarum }\end{array}$ \\
\hline $\begin{array}{l}\text { Sooty Mold } \\
\text { (minor, common in crops } \\
\text { grown under protected } \\
\text { cultivation) }\end{array}$ & $\begin{array}{l}\text { Velvety grey-black, fungal coating on the leaf } \\
\text { which is not pathogenic to plants but obtains its } \\
\text { nourishment from honeydews secreted by } \\
\text { small sucking insect pests like aphids, soft } \\
\text { scales and mealy bugs. The mould cover } \\
\text { reduces the plant's photosynthetic ability and } \\
\text { leaves may fall prematurely }\end{array}$ & $\begin{array}{l}\text { Meliola sp, Capnodium } \\
\text { sp. }\end{array}$ \\
\hline \multicolumn{3}{|c|}{ Diseases due to Virus } \\
\hline $\begin{array}{l}\text { Mosaic/Mottle } \\
\text { (major, occasional) }\end{array}$ & $\begin{array}{l}\text { Plants are stunted. Leaves and fruit are mottled } \\
\text { and become misshapen. CMV is spread by } \\
\text { aphids. TSWV is spread by thrips. PPMV is } \\
\text { mechanically transmitted }\end{array}$ & $\begin{array}{l}\text { Cucumber mosaic virus } \\
\text { (CMV) } \\
\text { Tomato spotted wilt virus } \\
\text { (TSWV), } \\
\text { Pepper Mild Mottle Virus } \\
\text { (PPMV) }\end{array}$ \\
\hline
\end{tabular}


Inventory and incidence of plant diseases affecting vegetables

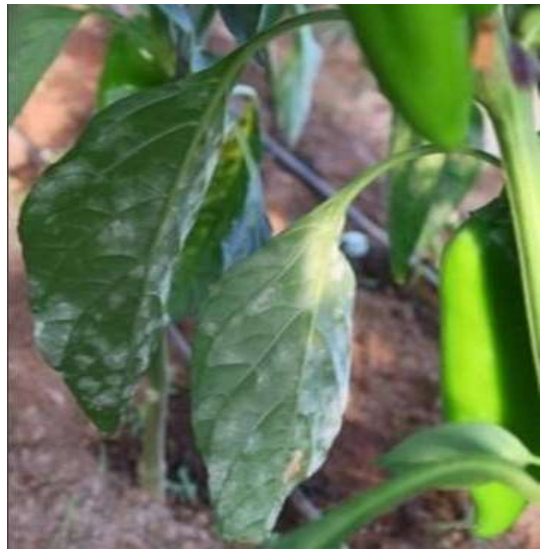

a

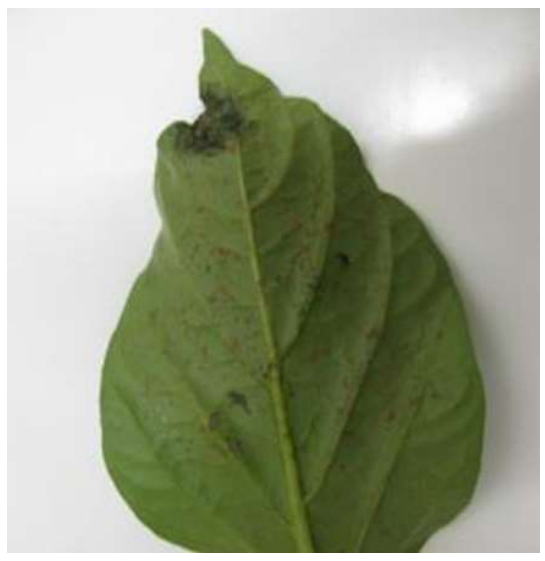

C

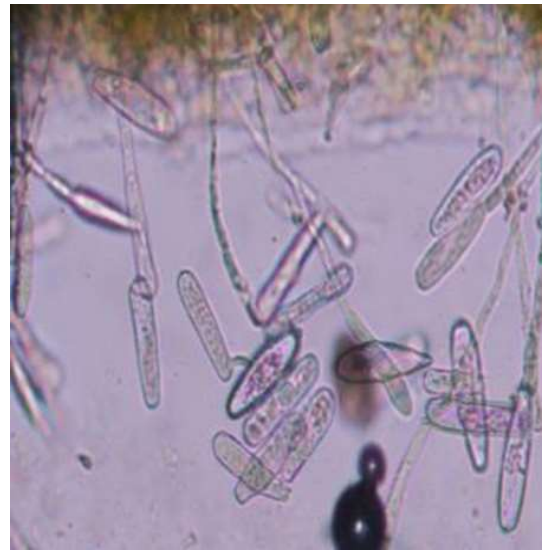

b

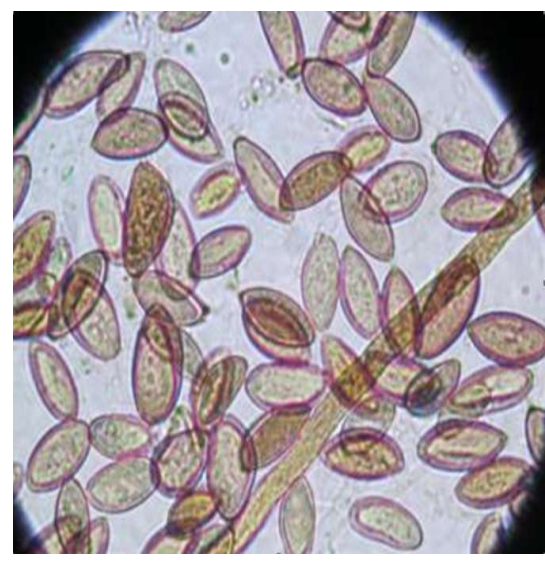

d

Figure 2. Powdery mildew diseases (a) Leveillula taurica (b), Choanephora blight (c) and the causal pathogen, Choanephora cucurbitarum (d)

In bittergourd, two diseases due to prokaryotes were monitored: bacterial wilt caused by Ralstonia solanacearum and little leaf/witches broom caused by Phytoplasma (Table 3). Six diseases were caused by fungi while only one virus disease was monitored. The most prevalent disease in Eastern Visayas is downy mildew caused by Pseudoperonospora cubensis which could be attributed to the wet climate. Bacterial wilt and "namamarako disease" were also common. Two diseases are considered emerging, little leaf/witches broom (Figure 3a-3b) and target spot caused by Corynespora cassiicola (Figure 3c \& 3d). Bittergourd witches broom in Myanmar was reported to be caused by Candidatus Phytoplasma asteris (Win et al 2014). Furthermore, bacterial wilt of bittergourd was caused by Ralstonia solanacearum and not Erwinia tracheiphila as has been commonly reported as the cause of bacterial wilt of cucurbits in most references. 
Borines et al

Table 3. Diseases of bittergourd, symptom description and causal organism

\begin{tabular}{lll}
\hline \multicolumn{3}{c}{ Diseases due to Bacteria and Mollicutes } \\
\hline \multicolumn{1}{c}{ Description/Symptoms } & Causal Organism \\
\hline & & Ralstonia \\
& & solanacearum/ \\
Bacterial Wilt & Plants wilt. Internal stem turns brown. Roots form on lower stem. & Ralstonia \\
(major, common) & Spread in contaminated water and soil. & pseudosolanace \\
& & arum \\
\hline
\end{tabular}

Little Small, thickened, yellowish green puckered leaves, the leaf/Witches internodes thicken and shorten leading to a witches broom Broom appearance, little and elongated fruits, flowers may show (emerging, phyllody symptoms. Flowers are reduced in size, does not fully getting more open at maturity and finally wither within a few days. Transmitted common: Figure by leafhoppers, particularly Ricania speculum and a cicadellid 3a \& 3b) leafhopper.

\begin{tabular}{|c|c|c|}
\hline & Diseases due to Fungi and Fungal-Like Organisms & \\
\hline $\begin{array}{l}\text { Seedling } \\
\text { Damping-off } \\
\text { (major, } \\
\text { occasional) }\end{array}$ & $\begin{array}{l}\text { Basal part of the stem becomes water-soaked and rotten which } \\
\text { cause the seedling to damp-off. Affected area may be covered } \\
\text { with mass of fungal growth. In pre-emergence damping-off, seeds } \\
\text { are rotten and fail to germinate. }\end{array}$ & $\begin{array}{l}\text { Pythium, } \\
\text { Phytophthora, } \\
\text { Sclerotium, } \\
\text { Rhizoctonia }\end{array}$ \\
\hline $\begin{array}{l}\text { Downy Mildew } \\
\text { (major and } \\
\text { common } \\
\text { in wet climate) }\end{array}$ & $\begin{array}{l}\text { Yellow irregular patches on the foliage which may become } \\
\text { necrotic and turn brownish. Whitish moulds may be seen present } \\
\text { on lower leaf surface. }\end{array}$ & $\begin{array}{l}\text { Pseudoperonospora } \\
\text { cubensis }\end{array}$ \\
\hline $\begin{array}{l}\text { Fusarium wilt } \\
\text { (major } \\
\text { occasional) }\end{array}$ & $\begin{array}{l}\text { Yellowing of leaves, initially from base of plant followed by wilting } \\
\text { and death of the entire plant. Vascular bundles in the collar region } \\
\text { becomes brown or yellowish. }\end{array}$ & $\begin{array}{l}\text { Fusarium } \\
\text { oxysporum f. } \\
\text { sp. momordicae }\end{array}$ \\
\hline $\begin{array}{l}\text { Cercosora } \\
\text { leafspot } \\
\text { (major, } \\
\text { occasional } \\
\text { Common) }\end{array}$ & $\begin{array}{l}\text { Small circular to irregular chlorotic spots with yellow halo around. } \\
\text { White to light tan in the center with darker brown margin. The } \\
\text { leaves may turn yellow and fall off. }\end{array}$ & Cercospora citrullina \\
\hline $\begin{array}{l}\text { Target spot } \\
\text { (emerging, } \\
\text { occasional: } \\
\text { Figure 3c \& 3d) }\end{array}$ & $\begin{array}{l}\text { Lesions start as small pinpoint water-soaked spots on the upper } \\
\text { surface which later turn brown and increasing in size. Lesions } \\
\text { with concentric rings are usually surrounded by yellow halo which } \\
\text { coalesce to form blighted leaves leading to premature defoliation. } \\
\text { Target-like spots brown necrotic spots on leaves. }\end{array}$ & $\begin{array}{l}\text { Corynespora } \\
\text { cassiicola }\end{array}$ \\
\hline
\end{tabular}


Inventory and incidence of plant diseases affecting vegetables

Table 3 continued

\begin{tabular}{|c|c|c|}
\hline \multicolumn{3}{|c|}{ Disease due to Bacteria and Mollicutes } \\
\hline & Description/Symptoms & Causal Organism \\
\hline $\begin{array}{l}\text { Basal stem rot } \\
\text { (major, } \\
\text { occasional) }\end{array}$ & $\begin{array}{l}\text { Loss of vigor, wilting leading to death of affected plants. Rotting of } \\
\text { the stem which particularly start at the base, with the formation of } \\
\text { a dense white mycelium which later turn into smooth spherical } \\
\text { structures measuring } ~ 1-3 \mathrm{~mm} \text { in diameter which start as which, } \\
\text { then light brown and later dark brown structures called sclerotia. }\end{array}$ & $\begin{array}{l}\text { Sclerotium } \\
\text { rolfsii, } \\
\text { Rhizoctonia } \\
\text { solani }\end{array}$ \\
\hline \multicolumn{3}{|c|}{ Diseases due to Virus } \\
\hline $\begin{array}{l}\text { "Namamarako } \\
\text { Disease" } \\
\text { (major, } \\
\text { occasional) }\end{array}$ & $\begin{array}{l}\text { Leaves thicken and wrinkled, sometimes leaf turn yellowish Vein } \\
\text { banding and stunted plants. Produce male flowers or no flowers. } \\
\text { Shiny and plastic-like appearance of leaves. }\end{array}$ & $\begin{array}{l}\text { Cucurbit Aphid-Borne } \\
\text { Yellows Virus } \\
\text { (CABYV) }\end{array}$ \\
\hline
\end{tabular}

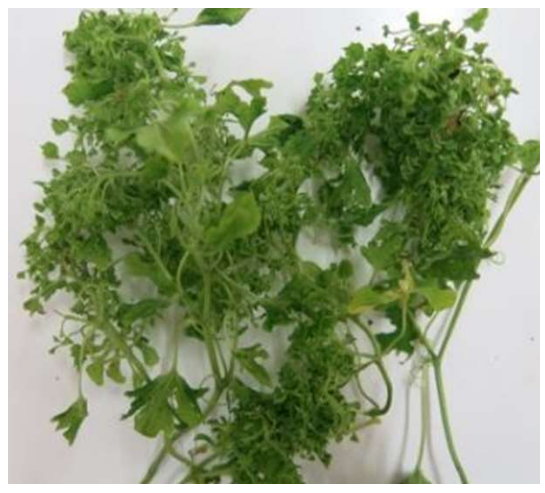

a

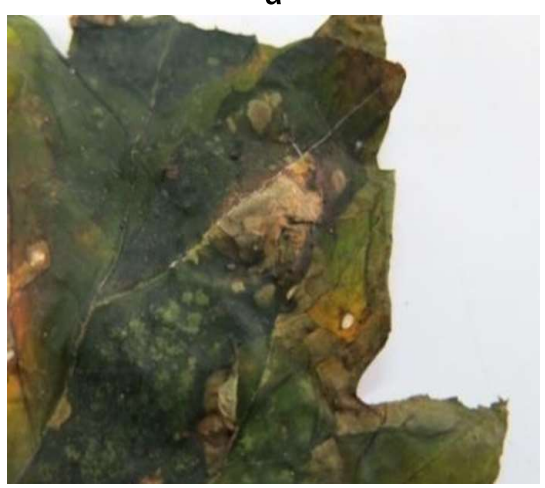

C

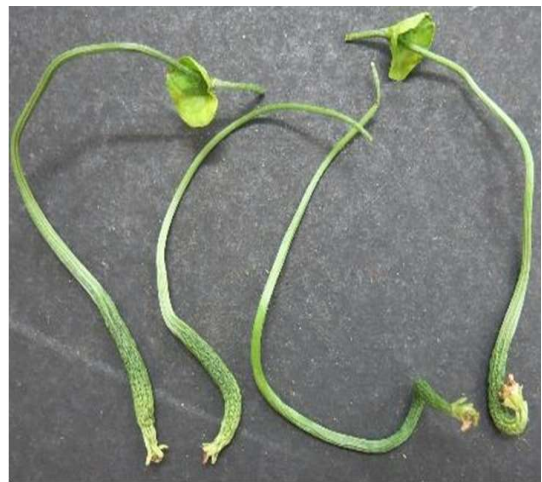

b

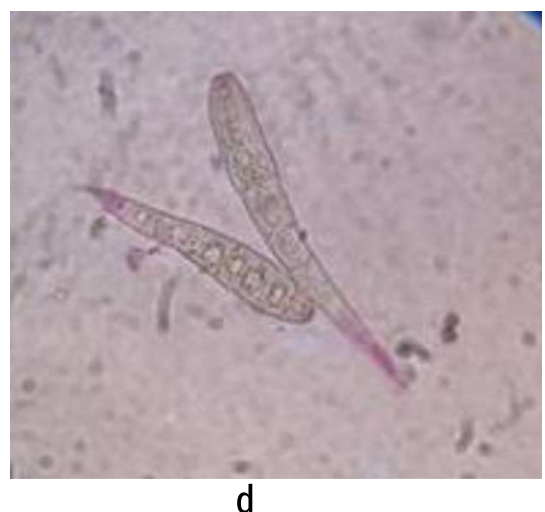

d

Figure 3. Emerging diseases of bittergourd, a-b) little leaf/witches broom caused by Phytoplasma and c-d) target spot caused by Corynespora cassiicola 
In eggplant, bacterial wilt was the only disease found to be caused by bacterium (Table 4). A yellow's type disease, which was suspected to be due to Phytoplasma was monitored but the causal organism was not confirmed through PCR analysis. Eight fungal diseases were found in eggplant: Fusarium wilt, Sclerotium wilt, Cercospora leaf spot, Phomopsis blight, Phytophthora blight and fruit rot, powdery mildew, basal stem rot and Choanephora blight (Figure 4). The latter disease is previously unreported in the published literature for eggplant in the Philippines, hence considered emerging. Two species of Phytophthora, confirmed through PCR analysis, were found on eggplant: Phytophtohra nicotianae and Phytophthora parasitica.

Table 4. Diseases of eggplant, symptom description and causal organism

\begin{tabular}{|c|c|c|}
\hline \multicolumn{3}{|c|}{ Diseases due to Bacteria and Mollicutes } \\
\hline & Description/Symptoms & Causal Organism \\
\hline $\begin{array}{l}\text { Bacterial Wilt } \\
\text { (major, common) }\end{array}$ & $\begin{array}{l}\text { Sudden wilting of plant, plant can die, root } \\
\text { system/stem damaged, dead, internal symptoms } \\
\text { include brown discoloration of the vascular vessels }\end{array}$ & $\begin{array}{l}\text { Ralstonia solanacearum/ } \\
\text { Ralstonia } \\
\text { pseudosolanace } \\
\text { arum }\end{array}$ \\
\hline \multicolumn{3}{|c|}{ Diseases due to Fungi and Fungal-Like Organisms } \\
\hline $\begin{array}{l}\text { Fusarium wilt } \\
\text { (major, occasional) }\end{array}$ & $\begin{array}{l}\text { Starts with yellowing of the lower leaves and wilting of } \\
\text { the plant with brownish internal vascular discoloration. }\end{array}$ & $\begin{array}{l}\text { Fusarium oxysporum } \\
\text { f.sp. melongenae }\end{array}$ \\
\hline $\begin{array}{l}\text { Sclerotium Wilt/Stem } \\
\text { Rot } \\
\text { (major, occasional) }\end{array}$ & $\begin{array}{l}\text { Wilting of the shoot, whitish mycelial mat can be seen } \\
\text { at the base, going up to the stem of the plant, initial } \\
\text { whitish round sclerotial bodies form which later turn } \\
\text { brown }\end{array}$ & Sclerotium rolfsii \\
\hline $\begin{array}{l}\text { Cercospora leafspot } \\
\text { (minor, occasional) }\end{array}$ & $\begin{array}{l}\text { Small, circular to oval chlorotic spots with light to dark } \\
\text { tan centers with dark spots that can be observed with } \\
\text { a hand lens or dissecting microscope. }\end{array}$ & Cercospora melongenae \\
\hline $\begin{array}{l}\text { Phomopsis } \\
\text { Blight/Fruit Rot } \\
\text { (minor occasional) }\end{array}$ & $\begin{array}{l}\text { Grey to brown lesions on fruit and may coalesce. Later } \\
\text { develops as soft, spongy rot with concentric patterns } \\
\text { and dark structures on the fruit surface. Yellowing of } \\
\text { leaves is evident and drops prematurely. }\end{array}$ & Phomopsis vexans \\
\hline $\begin{array}{l}\text { Phytophthora Blight } \\
\text { and Fruit Rot } \\
\text { (major, common in } \\
\text { wet climate) }\end{array}$ & $\begin{array}{l}\text { The roots and crowns turn brown and rot causing } \\
\text { plants to wilt. Infected fruits initially develop dark, } \\
\text { water-soaked patches that become coated with fluffy } \\
\text { white mycelia. Fruits may wither but remain attached } \\
\text { to the plant. fruit rot }\end{array}$ & $\begin{array}{l}\text { Phytophthora nicotianae } \\
\text { and } \\
\text { Phytophtora parasitica }\end{array}$ \\
\hline $\begin{array}{l}\text { Powdery Mildew } \\
\text { (minor occasional) }\end{array}$ & $\begin{array}{l}\text { Small irregular, whitish, powdery molds appear on } \\
\text { upper and lower leaf surfaces, which start at the older } \\
\text { leaves. Affected leaves eventually turn yellow and } \\
\text { necrotic }\end{array}$ & Erysiphe cichoracearum \\
\hline
\end{tabular}


Inventory and incidence of plant diseases affecting vegetables

\begin{tabular}{|c|c|c|}
\hline \multicolumn{3}{|c|}{ Diseases due to Fungi and and Fungal-Like Organisms } \\
\hline & Description/Symptoms & Causal Organism \\
\hline $\begin{array}{l}\text { Basal stem rot } \\
\text { (major, occasional) }\end{array}$ & $\begin{array}{l}\text { Loss of vigor, wilting leading to death of affected } \\
\text { plants. Rotting of the stem which particularly start at } \\
\text { the base, with the information of a dense white } \\
\text { mycelium which later turn into smooth spherical } \\
\text { structures measuring } 1-3 \mathrm{~mm} \text { in diameter which start } \\
\text { as which, then light brown and later dark brown } \\
\text { structures called sclerotia. }\end{array}$ & $\begin{array}{l}\text { Sclerotium rolfsii, } \\
\text { Rhizoctonia solani }\end{array}$ \\
\hline $\begin{array}{l}\text { Choanephora } \\
\text { Blight/Fruit Rot } \\
\text { (minor, occasional: } \\
\text { Figure 4) }\end{array}$ & $\begin{array}{l}\text { Starts with yellowed patches on leaves which } \\
\text { becomes blighted. In severe cases, blighting of the } \\
\text { entire shoot may occur and which may also affect the } \\
\text { fruits that appear rotten with mass of greyish fungal } \\
\text { growth. }\end{array}$ & $\begin{array}{l}\text { Choanephora } \\
\text { cucurbitarum }\end{array}$ \\
\hline
\end{tabular}

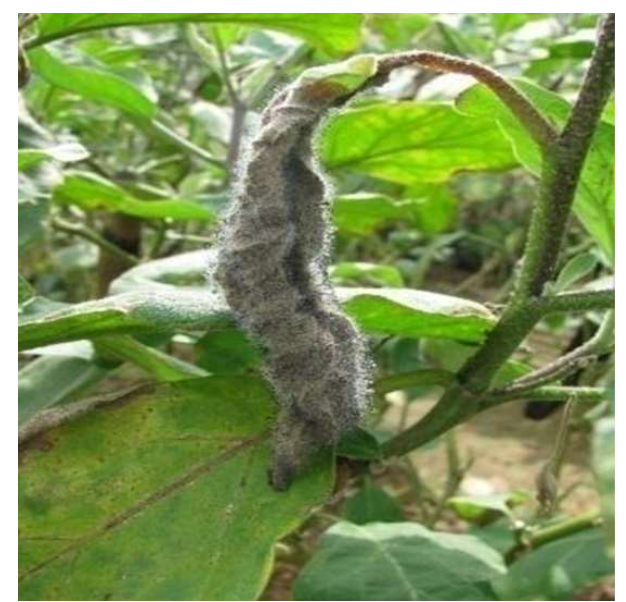

Figure 4.Choanephora blight of eggplant

In pechay, one bacterial disease (soft rot) and five fungal diseases were monitored (Table 5). The fungal diseases were: damping off, Sclerotium wilt, basal stem rot caused by Phytophthora sp. downy mildew by Peronospora parasitica (Figure 5a), the causal organism (Figure 5b), leaf spot caused by Curvularia lunata (Figure $5 c$ ) land Choanephora blight caused by $C$. cucurbitarum (Figure $5 d$ ). 
Borines et al

Table 5. Diseases of pechay, symptom description and causal organism

\begin{tabular}{|c|c|c|}
\hline \multicolumn{3}{|c|}{ Diseases due to Fungi and Fungal-Like Organisms } \\
\hline & Description/Symptoms & Causal Organism \\
\hline $\begin{array}{l}\text { Soft rot } \\
\text { (major, common) }\end{array}$ & $\begin{array}{l}\text { Bacterial soft rots cause water-soaked spots which } \\
\text { eventually enlarge over time and become sunken and } \\
\text { soft. A plant tissues breakdown and die they give off a } \\
\text { strong odour. }\end{array}$ & $\begin{array}{l}\text { Pectobacterium } \\
\text { carotovorum } \\
\text { pv. carotovorum }\end{array}$ \\
\hline Damping Off & $\begin{array}{l}\text { At seedling stage, stem at ground level becomes thin, } \\
\text { brown and plants fall over. Root system becomes } \\
\text { brown }\end{array}$ & $\begin{array}{l}\text { Pythium spp, } \\
\text { Phytopththora, } \\
\text { Sclerotium rolfsii and } \\
\text { Rhizoctonia solani }\end{array}$ \\
\hline $\begin{array}{l}\text { Sclerotium } \\
\text { Wilt/Southern Blight } \\
\text { (major, occasional) }\end{array}$ & $\begin{array}{l}\text { Loss of vigor, wilting leading to death of affected } \\
\text { plants. Rotting of the stem which particularly start at } \\
\text { the base, with the formation of a dense white } \\
\text { mycelium which later turn into smooth spherical } \\
\text { structures measuring } 1-3 \mathrm{~mm} \text { in diameter which } \\
\text { start as which, then light brown and later dark brown } \\
\text { structures called sclerotia. }\end{array}$ & Sclerotium rolfsii \\
\hline $\begin{array}{l}\text { Basal stem rot } \\
\text { (major, common in } \\
\text { wet climate) }\end{array}$ & $\begin{array}{l}\text { Rotting of the base and stem and blighting of leaves, } \\
\text { shoots and the whole plant. White mycelial growth } \\
\text { on the surface is present especially in very humid } \\
\text { conditions. Plants under moist conditions become } \\
\text { weak and die eventually. }\end{array}$ & Phytophthora sp. \\
\hline $\begin{array}{l}\text { Leaf spot } \\
\text { (minor, occasional) }\end{array}$ & $\begin{array}{l}\text { Light brown spot on leaves. Spots coalesce to form } \\
\text { blighted areas }\end{array}$ & Curvularia lunata \\
\hline $\begin{array}{l}\text { Downy Mildew } \\
\text { (major, occasional) }\end{array}$ & $\begin{array}{l}\text { Yellow spots on leaves, turning brown. Grey mould } \\
\text { present on lower leaf surface. Especially problem } \\
\text { during rainy season }\end{array}$ & Peronospora parasitica \\
\hline
\end{tabular}


Inventory and incidence of plant diseases affecting vegetables

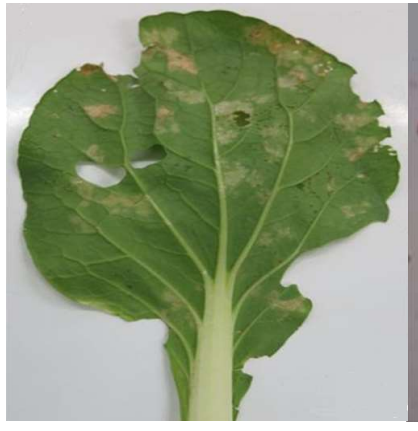

a

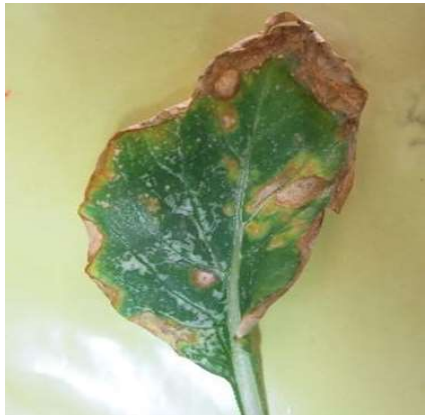

C

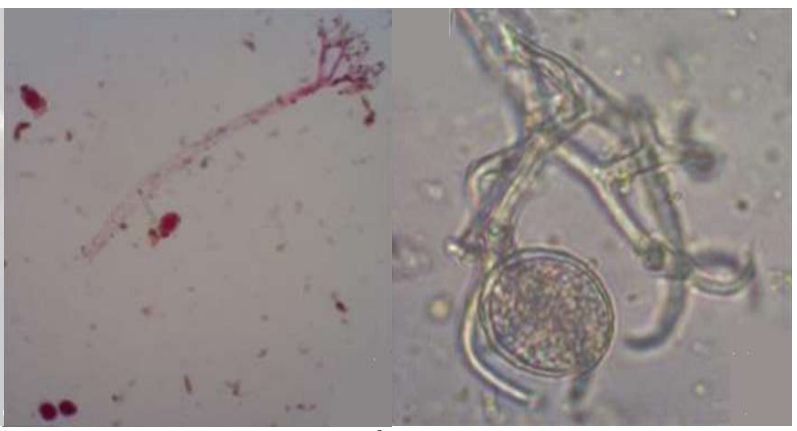

b

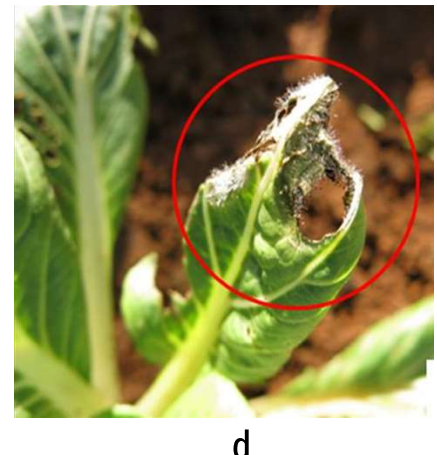

d

Figure 5. Diseases of pechay which are unreported particularly in Eastern Visayas Philippines (a) Downy mildew and (b) Peronospora parasitica the causal organism (c) Curvularia leaf spot and (d) Choanephorablight

In lettuce, a wilt disease was observed infecting the crop at the VSU experimental site where bacterial population is high. The disease was confirmed to be caused by Ralstonia solanacearum using an AGDIA immunodiagnostic strip. This wilt disease is considered emerging given that bacterial wilt has not been reported to infect lettuce in the Philippines. 
Borines et al

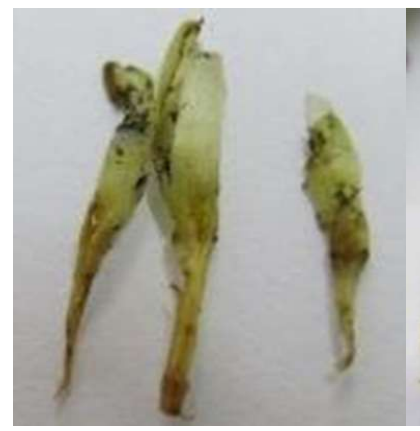

a

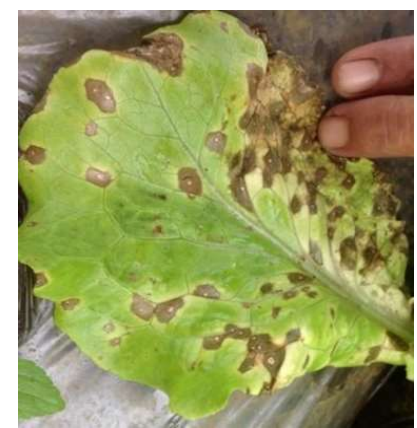

d

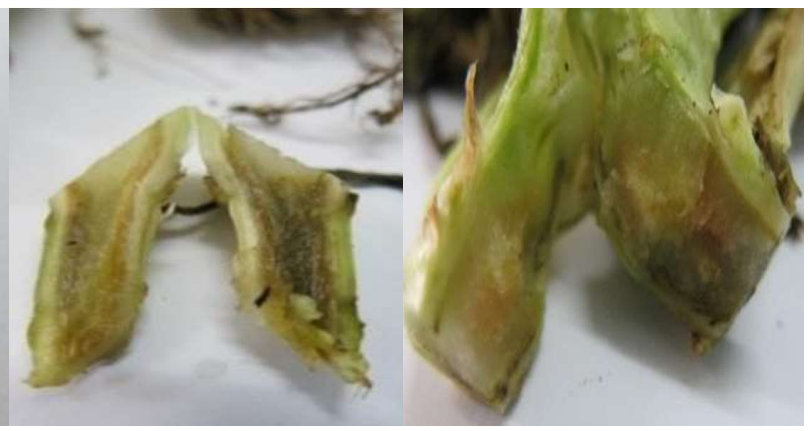

b

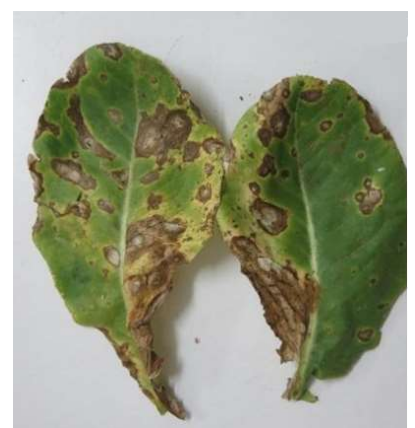

e

Figure 6. Wilt disease of lettuce with internal vascular discoloration diagnosed to be caused by Ralstonia solanacearum detected using an immunodiagnostic strip (Figure 6a-6c), and target spot caused by Corynespora cassiicola

Table 6. Inventoried diseases of lettuce, symptom description and causal organism

\begin{tabular}{|c|c|c|}
\hline \multicolumn{3}{|c|}{ Diseases due to Bacteria } \\
\hline & Description/Symptoms & Causal Organism \\
\hline $\begin{array}{l}\text { Bacterial Wilt } \\
\text { (emerging, rare) }\end{array}$ & $\begin{array}{l}\text { Lettuce plant showing browning of the basal part and } \\
\text { internal vascular tissues. Bacterial ooze coming out } \\
\text { from the symptomatic stem and positive result on } \\
\text { Ralstonia solanacearum immunodiagnostic strip. }\end{array}$ & Ralstonia solanacearum/ \\
\hline \multicolumn{3}{|c|}{ Diseases due to Fungi and Fungal-Like Organisms } \\
\hline $\begin{array}{l}\text { Target Spot } \\
\text { (emerging, } \\
\text { occasional) }\end{array}$ & $\begin{array}{l}\text { Brown to dark brown target-like spots on affected } \\
\text { leaves of lettuce with light and dark concentric rings, } \\
\text { circular to irregular, and } 5-15 \mathrm{~mm} \text { in diameter. Small } \\
\text { spots may increase in size, coalesce and may to } \\
\text { blight of affected leaves }\end{array}$ & Corynespora casiïcola \\
\hline $\begin{array}{l}\text { Sclerotium Wilt/Rot } \\
\text { major, occasional }\end{array}$ & $\begin{array}{l}\text { Rotting of leaves tissues that starts from the base } \\
\text { with formation of visible white mycelia and sclerotial } \\
\text { bodies which later turn brown }\end{array}$ & Sclerotium rolfsii \\
\hline
\end{tabular}


Inventory and incidence of plant diseases affecting vegetables

A catalog of vegetable diseases in Eastern Visayas was drafted as well as disease bulletins and factsheets, and translated into Cebuano and Waray-waray with disease management recommendations provided. These will guide farmers, and field technicians on how to manage these diseases.

\section{CONCLUSION}

The different diseases affecting tomato, pepper, eggplant, bittergourd, pechay and lettuce were documented, the causal organisms were identified and the major and emerging ones were also identified. This paper confirms that a wide variety of diseases affect vegetables and that new diseases are constantly emerging or vary in incidence from year to year, such that an inventory of diseases needs to be made from time to time to prevent possible outbreaks in the future.

\section{ACKNOWLEDGEMENTS}

Research support from the Australian Centre for Agricultural Research in Agriculture (ACIAR) and the Philippine Council for Agriculture, Aquatic and Natural Resources Research and Development (PCAARRD) are gratefully acknowledged and for the new laboratory microscopes.

\section{REFERENCES}

De la Cueva FM, Pascual CB, Bajet CM \& Dalisay TU. 2015. Pests and Diseases of Economically Important Crops in the Philippines. Pest Management Council of the Philippines, Inc. c/o Crop Protection Cluster, University of the Philippines Los Baños, College, Laguna

Sonkar P, Kumar V \& Sonkar A. 2013. Studies on cultural and morphological characters of tomato wilt (Fusariumoxysporum f.sp. lycopersici). International Journal of Bioassays 3(1):1637-1640

Tangonan NG and Quebral FC. 1992. Host index of plant diseases in the Philippines. (2nd edn) (pp273). University of Southern Mindanao at Kabacan

Tangonan NG. 1999. Host index of plant diseases in the Philippines (3rd edn) (pp408). Department of Agriculture, Philippine Rice Research Institute, Nueva Ecija

Vallad GE. 2018. Vegetable Pathology Program. Target spot and early blight of tomato. http://www.southeastagnet.com/documents/VegFactSheet-Tomatoearly\%20blight\%20and\%20target\%20spot.pdf

Win NKK, Kim WH \& Jung HY. 2014. Bittergourd little leaf disease associated to Candidatus Phytoplasma Asteris. Tropical Plant Pathology 39(1):082-088 